\title{
PENGEMBANGAN DESA EKOWISATA TERPADU SEBAGAI OPTIMALISASI POTENSI KAWASAN PANTAI PATEK BERBASIS UMKM DI DESA GELUNG SITUBONDO
}

\author{
Sulistyaningsih ${ }^{1}$, Sumarno $^{2}$ \\ Email : lis_sulistyaningsih@yahoo.com \\ ${ }^{1}$ Fakultas Pertanian, Universitas Abdurachman Saleh Situbondo
}

\begin{abstract}
Gelung village located in the district Panarukan, Situbondo, East Java province which has a huge potential in tourism and agriculture. Public awareness of the potential of tourism and farming village of Gelung need is developed as pathek beach tourism and seaweed farming as well as SMEs are mostly found in the village of Gelung. Looking at the problems and potential of the seed Gelung Village, held programs KKNPPM help alleviate the problem, utilizing the potential of the village, and empower an optimal and sustainable. Problem solving and how empowerment can be achieved with the cooperation of all parties, both from the public, government agencies and nongovernment, community organizations. Results achievement KKN PPM program implementation including the increase in participation and performance in the production of seaweed farming communities and SMEs. improvement of people's skills through training for a variety of seaweed processing, knowledge of food diversification, improved agriculture in early childhood and increased tourism knowledge. In the long run this program KKN PPM is an increase in the Community empowerment through increased per capita income through touch economics / business, given the increase in the human development index increased knowledge and skill touch people in the village of Bun on participation, both male and female population.
\end{abstract}

Keyword : Ecotourism, Patek Beach, Seaweed, SMEs

\section{PENDAHULUAN}

Desa Gelung terletak di Kecamatan Panarukan, Kabupaten Situbondo, Provinsi Jawa Timur. Kabupaten Situbondo merupakan sebuah kabupaten yang memiliki panjang pantai $\pm 168 \mathrm{~km}$ merupakan salah satu Kabupaten yang memiliki potensi sumber daya kelautan dan perikanan cukup besar, khususnya komoditi rumput laut Echeuma cottoni. Oleh karena itu Kabupaten Situbondo juga memiliki peluang besar untuk memacu pendapatan asli daerah melalui sektor kelautan dan perikanan. Hal ini nampak dari keseriusan Pemerintah Kabupaten Situbondo dalam memacu kegiatan pembangunan kelautan dan perikanan dengan menempatkan sektor ini dalam prioritas Perencanaan Pembangunan Daerah. 


\section{INTEGRITAS : Jurnal Pengabdian}

Vol 2, No 2, Desember 2018

ISSN 2580-7978 (Cetak) ISSN 2615-0794 (Online)

Petani rumput laut sebagai salah satu pelaku pembangunan kelautan dan perikanan yang memporoduksi komoditi eksport perlu mendapatkan perhatian dan pembinaan secara serius dan berkelajutan agar dapat menghasilkan produk yang berkualitas. Untuk dapat menghasilkan produk rumput laut yang dapat bersaing di pasaran perlu manajemen usaha yang profesional. Hal ini dapat terwujud kalau usaha rumput laut dijalankan oleh sumber daya manusia yang berkualitas mengingat komoditi ini rentan terhadap kualitas dan pemasaran.

Salah satu faktor masalah yang dihadapi pembudidaya atau petani rumput laut di desa Gelung ini adalah rendahnya kualitas rumput laut yang di hasilkan karena ketidakmampuan mereka memelihara sampai usia 45 hari yang di sebabkan mengalami kerontokan pada usia pemeliharaan, serangan hama penyakit. Selain itu petani kesulitan modal usaha sering memaksa petani menjual rumput lautnya pada usia 30 hari kondisi tersebut diatas di perparah dengan pemasaran situasi pada saat panen raya dimana harga rumut laut mengalami penurunan drastis. Adanya fluktuasi harga yang tidak menentu dan permainan harga dari para pengepul menyebabkan petani mengalami kerugian. Situasi semacam ini di alami petani hampir setiap tahun. Dengan jumlah petani rumput laut sebanyak 255 orang maka sangat perlu diberi pendampingan yang maksimal agar bisa benarbenar dirasakan pendapatan dari bertani rumput laut.

Desa Gelung juga memiliki potensi yang sangat besar dalam bidang pariwisata dan pertanian. Dari segi pertanian, Kecamatan Panarukan masih didominasi oleh lahan pertanian. Meski produktivitas hasil pertaniannya tergolong tinggi tetapi terjadi penurunan produksi yang disebabkan oleh tingginya konversi lahan pertanian menjadi lahan non pertanian. Hal ini menjadi ancaman serius di bidang pangan, mengingat jumlah penduduk di Kecamatan Panarukan tergolong padat.

Permasalahan lainnya di Desa Gelung yaitu kegiatan pemuda yang kurang berkembang serta kurangnya kesadaran masyarakat akan potensi-potensi pariwisata dan pertanian Desa Gelung. Selain itu, fasilitas dan infrastruktur yang mendukung pariwisata di Desa Gelung masih belum berfungsi secara maksimal. 


\section{INTEGRITAS : Jurnal Pengabdian}

Melihat permasalahan-permasalahan dan potensi unggulan Desa Gelung tersebut, kami mengadakan program-program KKN-PPM yang membantu mengentaskan permasalahan, memanfaatkan potensi desa, serta memberdayakan masyarakat secara optimal dan berkesinambungan. Adapun usulan penyelesaian masalah dan cara pemberdayaan masyarakat dapat dicapai dengan kerja sama dari seluruh pihak, baik dari masyarakat, lembaga pemerintah dan non- pemerintah, organisasi masyarakat. Setiap lapisan masyarakat memiliki tanggung jawab yang sama dalam mengembangkan pariwisata desa dan menyelesaikan masalah lingkungan hidup.

Kami dari KKN-PPM akan mencoba memfasilitasi dan memberikan pemberdayaan masyarakat untuk menciptakan seluruh lapisan masyarakat yang peduli atas kelestarian lingkungan hidup dan menyadari akan potensi sumber daya alam yang bisa dikembangkan, sehingga tujuan kami untuk meningkatan mutu perekonomian rakyat melalui pengembangan potensi sumber daya alam dapat tercapai lewat program-program lanjutan dari organisasi masyarakat atau dari pihak pemerintah.

Kegiatan-kegiatan yang kami susun tidak hanya memberikan pemberdayaan masyarakat secara temporer, kami juga mendasarkan pada metode Education for Sustainable Development (ESD) yang akan digunakan untuk mengatasi berbagai permasalahan yang ada. Kegiatan ESD yang akan dilaksanakan meliputi pendidikan untuk pengembangan program berkelanjutan sebagai media yang efektif dan edukatif yaitu dengan menerjunkan mahasiswa ketengah-tengah masyarakat yang akan menangkap dan mengembangkan pola pikir yang berimbang dengan mencakup triple bottom line dalam yakni saling keterkaitan antar sektor ekonomi, sosial, dan lingkungan.

Secara khusus metode pemberdayaan masyarakat yang ada pada KKN-PPM kami ialah meliputi pengembangan bidang pemberdayaan hukum, teknik, ekonomi, dan pertanian. Dengan basis pendidikan untuk masa jangka panjang diharapkan menjadi langkah yang baik untuk menanggulangi dan bahkan menjaga 


\section{INTEGRITAS : Jurnal Pengabdian}

Vol 2, No 2, Desember 2018

ISSN 2580-7978 (Cetak) ISSN 2615-0794 (Online)

keberlangsungan Kabupaten Situbondo, khususnya Desa Gelung sebagai desa yang menyadari banyaknya sumber daya alam yang berpotensi untuk dikembangkan, sehingga bisa tercipta Desa Gelung yang memiliki ekosistem alam yang seimbang. Adapun yang akan kami jadikan mitra diantaranya adalah Dinas Kelautan dan Perikanan Pemerintah Kabupaten Situbondo mengingat pantai pathek dan kelautan di Desa Gelung merupakan salah satu area yang menjadi tugas pokok dinas terkait dalam pemeliharan aset daerah tersebut. Pemerintah Desa dan BPD desa setempat juga akan terlibat dalam KKN - PPM ini.

Hal ini juga akan menguntungkan dari segi industri pariwisata karena Situbondo sebagai salah satu jalur darat menuju wisata dunia yaitu Bali tentunya disadari sebagai suatu aset yang berharga bagi bangsa Indonesia. Dengan pengadaan desa wisata tentunya akan semakin menarik perhatian para wisatawan yang akan menuju tempat wisata di Jawa Timur.

\section{METODE PELAKSANAAN}

\section{Pesiapan dan Pembekalan}

KKN-PPM ini diawali dengan pembekalan kepada peserta mengenai filosofi, ruang lingkup, etika, administrasi, serta keselamatan yang harus diperhatikan selama berada dilokasi. Tema dasar Program KKN yang dirancang adalah "Pengembangan Kehidupan Sosial-Budaya Berbasis Potensi Lokal". Secara umum program KKN-PPM dirancang untuk menciptakan dan mengoptimalkan potensi sumber daya yang ada dalam hal ini adalah desa wisata Gelung melalui berbagai program pengembangan untuk peningkatan kehidupan sosial, ekonomi, dan budaya masyarakat lokal.

Secara khusus fokus pengembangan pada KKN-PPM tahun pertama adalah "Pengembangan Desa Ekowisata Terpadu Sebagai Optimalisasi Potensi Pantai Pathek Serta Potensi Budidaya Rumput Laut Berbasis Teknologi Informasi dan UMKM". Pada penerjunan pertama, KKN difokuskan pada program-program yang terkait dengan "penyiapan dan pemantapan fasilitas dan infrastruktur masyarakat lokal" terutama yang mendukung pengembangan pariwisata, 


\section{INTEGRITAS : Jurnal Pengabdian}

Vol 2, No 2, Desember 2018

ISSN 2580-7978 (Cetak) ISSN 2615-0794 (Online)

pertanian dan UMKM. Pemanfaatan teknologi informasi akan sangat mendukung kelancaran kegiatan tersebut. Secara operasional, beberapa jenis kegiatan antara lain translate bahasa (menerjemahkan informasi dan website pariwisata lokal ke dalam bahasa asing serta penambahan papan informasi di objek-objek wisata secara dwibahasa atau bahasa asing lainnya), program kolaborasi budaya (short course "fire dance") dengan sasaran para pemuda lokal, pembangunan infrastruktur berupa jalan setapak untuk tracking wisata dan meningkatkan infrastruktur menuju desa wisata Gelung.

Pada penerjunan kedua, KKN difokuskan program-program, yang mengarah pada "intensifikasi dan ekstensfikasi produksi dari berbagai potensi produk lokal" baik di bidang pertanian, industri kecil maupun yang lainnya. Secara opreasional beberapa jenis kegiatan antara lain pengenalan dan pemasarakatan pemanfaatan tanaman rumput laut, pengembangan industri pengolahan hasil perikanan serta peningkatan infrastruktur berupa penginapan bagi wisatawan dan perbaikan jalan menuju Desa Gelung.

Sedangkan pada penerjunan ketiga, KKN difokuskan pada program-program yang terkait dengan "penciptaan nilai tambah atas produk lokal". Secara opreasional beberapa jenis kegiatan antara lain berupa peningkatan dan penganekaragaman industri pengolahan (misalnya industri produk rumput laut, produk perikanan, produk pertanian lainnya, produk kerajinanan, dll) dengan harapan produk-produk tersebut memiliki nilai jual yang lebih baik (tercipta value added).

\section{Pelaksanaan}

Pelaksanaan dari program KKN-PPM ini akan dibagi dalam tiga kegiatan, yaitu program utama dan program pendukung. Dalam tiap-tiap program juga akan dilaksanakan beberapa langkah- langkah operasional yang akan dikerjakan dalam mencapai tujuan akhir.

a. Program utama:

Program Kluster Sosial-Humaniora 


\section{INTEGRITAS : Jurnal Pengabdian}

Vol 2, No 2, Desember 2018

ISSN 2580-7978 (Cetak) ISSN 2615-0794 (Online)

Pembinaan UMKM dan Pemberdayaan Masyarakat

1) Video Profil Desa

2) Pelatihan Pengolahan Rumput Laut

3) Proyek menerjemahkan informasi dan website pariwisata lokal ke dalam bahasa asing

4) Penambahan papan informasi di objek-objek wisata secara dwibahasa atau bahasa asing lainnya

5) Pengembangan potensi Desa Gelung melalui foto-foto

6) Sosialisasi hukum pariwisata

7) Kerja bakti "bersih desa"

b. Program Pendukung:

Program Kluster Pertanian

Pengembangan Sarana dan Prasarana di Bidang Pertanian

1) Pengenalan pertanian usia dini

2) Penyuluhan diversifikasi pangan

3) Potensi kawasan wisata Desa Gelung

4) Penyuluhan pengoptimalan lahan dengan cara ancak

5) Penanaman bersama rumput laut secara ancak

6) Pembuatan Pengklasifikasian dan pemberian nama ilmiah untuk ditempatkan pada tiap-tiap tanaman pada kawasan wisata

7) Pembagian bibit rumput laut dan penyuluhan cara budidaya serta pemanfaatan hasilnya

8) Potensi sektor perikanan di Desa Gelung

c. Program Kluster Sains dan Teknologi

Pengelolaan Lingkungan dan Tata Kelola Wilayah.

1) Program short course sosialisasi pembinaan pelatihan komputer dan pengenalan wawasan IT masyarakat sekitar

2) Pengecatan tembok balai desa

3) Pembuatan dan pemasangan denah desa 


\section{INTEGRITAS : Jurnal Pengabdian}

Vol 2, No 2, Desember 2018

ISSN 2580-7978 (Cetak) ISSN 2615-0794 (Online)

4) Leterisasi desa

5) Pengembangan hard-skill pada bidang IT, Sains, dan Teknik

\section{HASIL DAN PEMBAHASAN}

\section{Hasil Pengabdian KKN - PPM}

Dalam jangka panjang program KKN PPM ini adalah peningkatan pemberdayaan masyarakan melalui peningkatan income perkapita melalui sentuhan bidang ekonomi / usaha ,peningkatan indeks pembangunan manusia mengingat sentuhan peningkatan pengetahuan dan ketrampilan masyarakat di Desa Gelung pada aspek partisipasi penduduk baik pria maupun wanita.

Secara umum hasil capaian pelaksanaan program KKN PPM antara lain :

- Peningkatan partisipasi dan kinerja produksi pada masyarakat tani rumput laut dan UMKM.

- Perbaikan sistem produksi pada lingkup teknik budidaya.

- Peningkatan keterampilan masyarakat melalui pelatihan pengolahan aneka hasil rumput laut sehingga dihasilakan produk yang tidak saja higienis tapi juga variatif.

- Peningkatan pengetahuan masyarakat akan deversifikasi pangan sehinggga dapat menekan ketergantungan konsumsi beras.

- Peningkatan pengetahuan bidang pertanian pada anak usia dini sehingga membuka wawasan cakrawala pertanian lebih luas.

- Peningkatan pengetahuan pariwisata sehingga masyarakat mengerti dan memahami hukum pariwisata utamanya pada tingkat perangkat desa dan UMKM.

- Pengembangan promosi melalui www.desagelung.blogspot.com sehingga diperoleh peningkatan kunjungan wisata pantai patek.

Sebagaimana pada bab sebelumnya program - program KKN PPM secara rinci hasil nya dapat dijelaskan pada tabel sebagai berikut: 


\section{INTEGRITAS : Jurnal Pengabdian}

Vol 2, No 2, Desember 2018

ISSN 2580-7978 (Cetak) ISSN 2615-0794 (Online)

Tabel 1. Hasil Pelaksanaan KKN PPM Di Desa Gelung Kecamatan Panarukan Kabupaten Situbondo

\begin{tabular}{|c|c|c|c|}
\hline No & Sektor & Program & Hasil \\
\hline 1. & $\begin{array}{l}\text { Program utama: } \\
\text { Program Kluster } \\
\text { Sosial-Humaniora } \\
\text { Pembinaan dan } \\
\text { UMKM Pe } \\
\text { Pemberdayaan } \\
\text { masyarakat }\end{array}$ & 1. Video profil Desa & $\begin{array}{lll}\text { Video siap } & \text { putar, } \\
\text { promosi. } & & \end{array}$ \\
\hline & & $\begin{array}{l}\text { 2. Pelatihan Pengolahan } \\
\text { Rumput laut }\end{array}$ & $\begin{array}{l}\text { Peningkatan ketrampilan } \\
\text { masyarakat }\end{array}$ \\
\hline & & $\begin{array}{l}\text { 3. Penambahan papan } \\
\text { informasi di obyek } \\
\text { wisata secara dwibahasa }\end{array}$ & $\begin{array}{lr}\text { Terpasangnya } & \text { papan } \\
\text { informasi } & \text { dengan } \\
\text { dwibahasa } & \end{array}$ \\
\hline & & $\begin{array}{l}\text { 4. Pengembangan potensi } \\
\text { Desa Gelung melalui } \\
\text { Foto-foto }\end{array}$ & $\begin{array}{l}\text { Dokumentasi foto yang } \\
\text { bisa di uppload di internet } \\
\text { masyarakat lebih } \\
\text { mengetahui obyek wisata } \\
\text { serta potensi Desa } \\
\text { Gelung. }\end{array}$ \\
\hline & & $\begin{array}{ll}\text { 5. Sosialisasi } & \text { hukum } \\
\text { pariwisata } & \end{array}$ & $\begin{array}{l}\text { Masyarakat paham dan } \\
\text { mengerti undang-undang } \\
\text { pariwisata }\end{array}$ \\
\hline & & 6. Kerja bakti bersih desa & $\begin{array}{ll}\text { Masyarakat } & \text { cinta } \\
\text { lingkungan bersih } & \end{array}$ \\
\hline 2. & $\begin{array}{l}\text { Program } \\
\text { Pendukung: } \\
\text { Program Kluster } \\
\text { Pertanian } \\
\text { Pengembangan } \\
\text { sarana dan } \\
\text { prasarana di } \\
\text { bidang pertanian }\end{array}$ & 1.Pengenalan pertanian usia dini & $\begin{array}{l}\text { Peningkatan } \\
\text { pengetahuan,wawasan } \\
\text { bidang pertanian pada } \\
\text { anak-anak }\end{array}$ \\
\hline & & $\begin{array}{l}\text { 2. Penyuluhan diversifikasi } \\
\text { pangan }\end{array}$ & $\begin{array}{l}\text { Tercipta keanekaragaman } \\
\text { pangan dan menekan } \\
\text { ketergantungan konsumsi } \\
\text { beras }\end{array}$ \\
\hline & & $\begin{array}{l}\text { 3. Potensi kawasan wisata Desa } \\
\text { Gelung }\end{array}$ & $\begin{array}{l}\text { Pengoptimalan obyek } \\
\text { wisata }\end{array}$ \\
\hline & & $\begin{array}{l}\text { 4.Penyuluhan budidaya rumput } \\
\text { laut secara ancak dan longline }\end{array}$ & $\begin{array}{ll}\text { Perbaikan } & \text { teknik } \\
\text { budidaya } & \end{array}$ \\
\hline & & 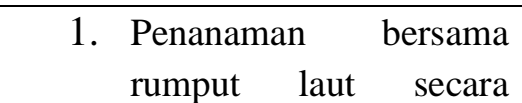 & $\begin{array}{l}\text { Peningkatan } \text { partisipasi } \\
\text { masyarakat }\end{array}$ \\
\hline
\end{tabular}




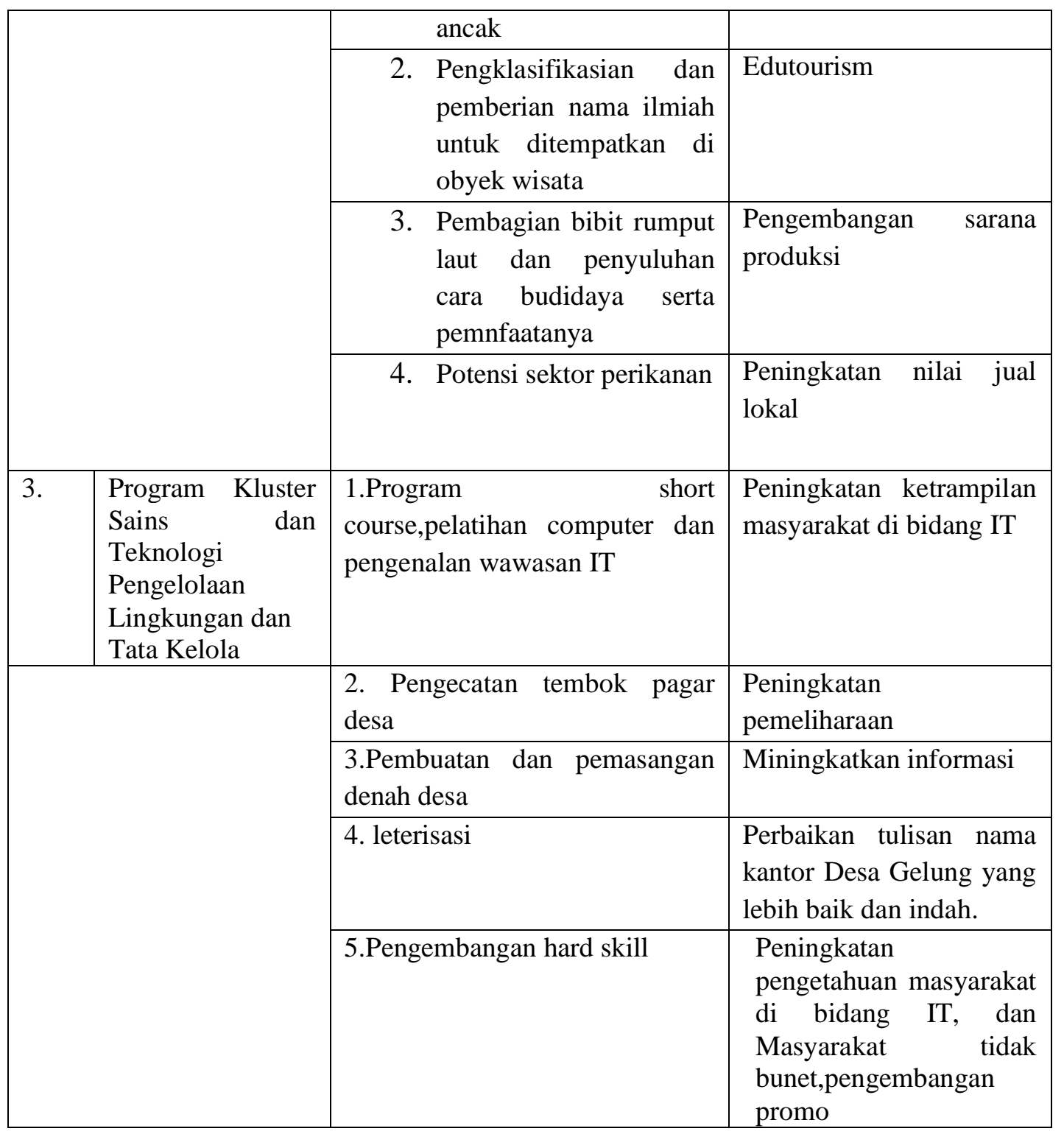

\section{Pembahasan Pengabdian KKN-PPM}

Program Utama : Kluster Sosial Humaniora - Pembinaan UMKM dan Pemberdayaan Masyarakat.

\section{a.Pembuatan Video Profil Desa Gelung}

Video profil Desa Gelung di lakukan dengan beberapa kali pengambilan gambar pada kegiatan-kegiatan dan obyek-obyek wisata maupun UMKM secara bertahap mulai tanggal 3-8 Mei 2014 Dengan di buatnya video profil Desa Gelung akan memudahkan mayarakat memahami potensi-potensi yang dimiliki 


\section{INTEGRITAS : Jurnal Pengabdian}

Vol 2, No 2, Desember 2018

ISSN 2580-7978 (Cetak) ISSN 2615-0794 (Online)

Desa ini seperti misalnya potensi perikanan, peternakan, pertanian, home industri serta wisatanya selain itu dengan dikemas melalui CD maka memudahkan dibawa kemana - mana untuk mempromosikan Gelung pada khalayak umum sehingga berdampak positif pada sektor perekonomian masyarakat dan akan lebih banyak lagi yang berkunjung dipantai Patek.

\section{b.Pelatihan Pengolahan Rumput laut}

Salah satu kendala yang ditemukan pada saat survey di lapangan yakni petani rumput laut menjual produksinya dalam bentuk produk basah atau kering padahal sebagai daerah yang memiliki potensi wisata setidaknya terdapat produk olahan rumput laut dan masyarakat Gelung belum menangkap peluang ini untuk di komersialkan. Kegiatan pelatihan pengolahan rumput laut merupakan solusi terhadap pemecahan masalah tersebut dan kegiatan ini dilaksanakan pada tanggal 19 Juni 2014. Masyarakat Gelung sangat antusias melaksanakan kegiatan ini, bahkan minta kegiatan pelatihan ini di lakukan ulang pada kesempatan lain .

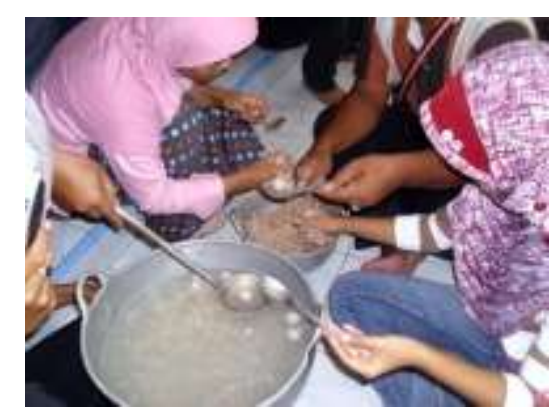

Gambar. Proses Pelatihan Pembuatan Bakso Rumput Laut

Masyarakat Desa Gelung merasakan manfaat untuk mengembangkannya, adanya pelatihan ini antara lain dapat meningkatkan ketrampilan , pengetahuan dan dengan harapan manakala hasil dari pelatihan ini terus dikembangkan terutama ibu-ibu dapat membuat aneka produk olahan rumput laut yang bisa di jual atau dipasarkan warung-warung yang berada di sepanjang pantai Patek dan sekitarnya. Aneka produk olahan rumput laut yang khas ini dapat dijadikan 


\section{INTEGRITAS : Jurnal Pengabdian}

Vol 2, No 2, Desember 2018

ISSN 2580-7978 (Cetak) ISSN 2615-0794 (Online)

sebagai daya tarik pengunjung / wisatawan untuk datang berlibur ke pantai Patek. Sehingga secara tidak langsung dapat meningkatkan pendapatan keluarga secara khusus dan perekonomian masyarakat secara umum.

\section{c.Penambahan Papan Informasi di Obyek Wisata secara Dwibahasa}

Pemesanan papan informasi dilakukan pada tanggal 9 Mei 2014 dan di pasang pada tanggal 17 Mei 2014. Dalam rangka menggali potensi yang ada di Desa Gelung melalui obyek wisatanya dan dengan adanya papan informasi ini dapat memudahkan wisatawan baik asing maupun domestik dalam menerima informasi serta melatih masyarakat belajar bahasa asing. Selain memberikan motivasi bagi anak-anak usia sekolah untuk lebih menguasai bahasa asing terutama bahasa inggris sebagai bahasa international .

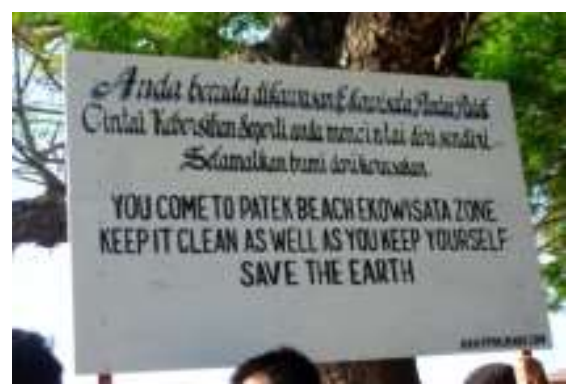

Gambar 2. Pemasangan Papan Informasi Dwi Bahasa

era globalisasi kedepan penggunaan bahasa asing /inggris tidak bisa dielakkan lagi, papan dwi bahasa sebagai contoh membangkitkan gairah masyarakat untuk memahami maksud tersebut diatas.

\section{d.Pengembangan Potensi Desa Gelung melalui Foto-foto}

Berbagai macam upaya untuk mempromosikan potensi Desa Gelung salah satunya adalah promosi melalui foto-foto kegiatan ini dilaksanakan pada tanggal 


\section{INTEGRITAS : Jurnal Pengabdian}

Vol 2, No 2, Desember 2018

ISSN 2580-7978 (Cetak) ISSN 2615-0794 (Online)

27 April 2014 . Hasil dokumentasi foto-foto di uppload ke internet sehingga masyarakat luar desa maupun luar kota menjadi mengetahui potensi yang dimiliki oleh Desa Gelung.

\section{e.Informasi melalui Website}

Teknologi informasi saat ini tidak bisa di hindarkan lagi dengan adanya web yang prosesnya dibuat mulai tanggal 29 April 2014 memudahkan wisatawan baik domestik maupun asing dalam menerima informasi tentang wisata pantai Patek . Dan sejak tanggal 16 Mei 2014 masyarakat dapat mengakses melalui www.desagelung.blogspot.com .Pengembangan promosi melalui web dapat meningkatkan kunjungan wisata pantai Patek.

\section{f.Sosialisasi Hukum Pariwisata}

Mengacu pada undang-undang No 10 tahun 2009 tentang kepariwisataan ,yang dimaksud dengan Wisata adalah kegiatan perjalanan yang dilakukan oleh seseorang atau sekelompok orang dengan mengunjungi tempat tertentu untuk tujuan rekreasi,pengembangan pribadi, atau mempelajari keunikan daya tarik wisata yang dikunjungi dalam jangka waktu sementara. Penyuluhan dilaksanakan pada tanggal 14 Juli 2014, maksud diselenggarakannya sosialisasi hukum pariwisata adalah memberikaan wacana pengetahuan tentang kepariwisataan sehingga masyarakat pelaku yang langsung langsung maupun tidak langsung dalam kegiatan kepariwisataan menjadi paham dan tahu misal tentang tujuan penyelenggaraan kepariwisataan, jenis-jenis usaha pariwisata ,hak dan kewajiban serta larangan dll ,sehingga mampu menciptakan suasana yang nyaman harmonis yang pada akhirnya meningkatkan daya kunjung wisatawan.

\section{g.Kerja Bakti Bersih Desa}

Untuk menciptakan masyarakat yang cinta lingkungan bersih maka setiap hari sabtu diadakan kerja bakti bersih desa oleh peserta KKN PPM bersama masyarakat, awalnya kegiatan ini di mulai dari lingkungan balai desa ,jalan jalan didesa dan seputar pantai wisata Patek. Para pemilik warung di himbau untuk menjaga kebersihan dilingkungan masing-masing, lingkungan yang bersih 


\section{INTEGRITAS : Jurnal Pengabdian}

Vol 2, No 2, Desember 2018

ISSN 2580-7978 (Cetak) ISSN 2615-0794 (Online)

membuat pengunjung pantai Patek akan betah dan nyaman menikmati panorama pantai yang indah sambil menikmati makanan dan minuman yang tersedia.

\section{Pengembangan Sarana dan Prasarana di Bidang Pertanian \\ a.Pengenalan Pertanian Pada Usia Dini}

Kegiatan ini Penyuluhan Pertanian pada anak usia dini dilaksanakan pada tanggal 17 Juni 2014 bertempat di SDN I Gelung Kecamatan Panarukan Kabupaten Situbondo , penyuluhan ini diikuti oleh anak -anak siswa kelas 4-6, dan berlangsung secara lancar dengan antusias atau semangat yang tinggi dari perserta didik dan tidak hanya kepala sekolah dan para guru yang senang terhadap kegiatan ini lebih-lebih siswa, dengan adanya kegiatan penyuluhan ini dapat meningkatkan pengetahuan, wawasan pertanian pada anak -anak sehingga mereka mengenal, mengerti dan menumbuhkan rasa cinta terhadap Negara yang notabene Indonesia merupakan Negara agraris.

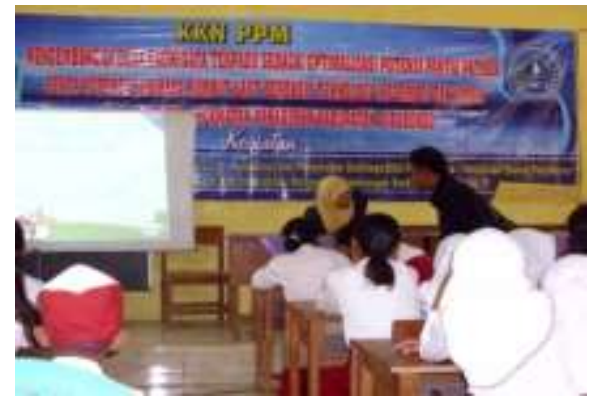

Gambar 3. Pengenalan Pertanian Pada Usia Dini

\section{b. Penyuluhan Diversivikasi Pangan}

Tradisi Makan. Dalam masyarakat kita, jawaban atas pertanyaan "sudah makan atau belum” ternyata menunjukkan pengaruh yang tidak kecil terhadap 


\section{INTEGRITAS : Jurnal Pengabdian}

Vol 2, No 2, Desember 2018

ISSN 2580-7978 (Cetak) ISSN 2615-0794 (Online)

konsumsi beras per kapita. Pengertian makan di sebagian besar masyarakat masih sangat identik dengan nasi yang terbuat dari beras. Di luar itu akan menyatakan belum makan walaupun sudah makan roti atau bahkan nasi goreng sekalipun. Padahal, dilihat dari nilai gizinya, roti apalagi campur keju dan mentega dengan minum susu, atau nasi goreng dengan dadar telur jauh lebih bergizi dibandingkan dengan sekadar makan nasi putih dengan lauk ikan asin. Diversifikasi pangan pokok adalah "usaha untuk menyediakan berbagai ragam produk pangan baik dalam jenis maupun bentuk, sehingga tersedia banyak pilihan bagi konsumen untuk menu makanan harian".

Diversifikasi pangan terbagi menjadi tiga:

- Diversifikasi hosirontal (aneka bahan)

- Diversifikasi vertikal (aneka hasil olahan)

- Diversifikasi regional (wilayah dan sosial budaya)

Kegiatan penyuluhan diversifikasi pangan dilaksanakan pada tanggal 14 Juli 2014 bertempat di Balai Desa yang dihadiri 25 orang peserta, tujuan kegiatan ini adalah memberikan pengetahuan pada masyarakat dan terciptanya keanekaragaman pangan dan menekan ketergantungan konsumsi beras.

\section{c.Potensi Kawasan Wisata Desa Gelung.}

Pengoptimalan Obyek wisata Pantai Patek seperti misal keindahahan pantainya dilakukan demi menggali sebanyak-banyaknya potensi Desa Gelung untuk di eksplore agar lebih dikenal masyarakat luas diluar Gelung.

\section{d.Penyuluhan Budidaya Rumput Laut secara Ancak dan longline.}

Silaturahmi datang ke kelompok tani rumput laut yang ada di Desa Gelung pada tanggal 14 - 15 Mei 2015 dan Penyuluhan budidaya rumput laut dor to dor ke petani pada tanggal 31 Mei 2014,model pendekatan penyuluhan yang dilakukan seperti tersebut diatas lebih mengena karena petani tidak merasa digurui dan terjalin keakraban antara pelaksana, peserta KKN PPM dengan petani. 


\section{INTEGRITAS : Jurnal Pengabdian}

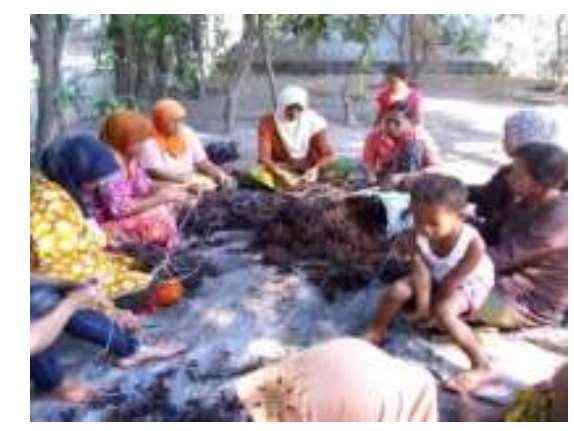

Gambar 4. Penyuluhan Budidaya Rumput Laut

Materi yang disampaikan menyangkut teknik budidaya rumput laut secara ancak dan longline, kebanyakan petani dalam mengikat bibit jarak ikatannya terlampau dekat alasan mereka supaya lebih banyak yang ditanam namun secara teknik cara demikian bibit rumput laut tersebut ,umur panen dan pasca panen.

\section{e.Penanaman Bersama Rumput Laut secara Ancak.}

Secara umum petani rumput laut mengalami kekurangan modal dalam mengembangkan usahanya. Diawali dengan pemberian bantuan bibit rumput laut tanggal 10 Juni 2014 pada salah satu kelompok tani rumput laut dan dilanjutkan dengan proses nyandik yaitu proses pra tanam yakni pengikatan bibit rumput laut pada tali sebelum ditanam ,proses ini biasanya dilakukan oleh kaum ibu. Setelah proses nyandik dan persiapan lainnya seperti pembuatan ancak dll baru bibit tersebut di tanam di pantai dengan kedalaman $\pm 40 \mathrm{Cm}$ dari permukaan air laut.

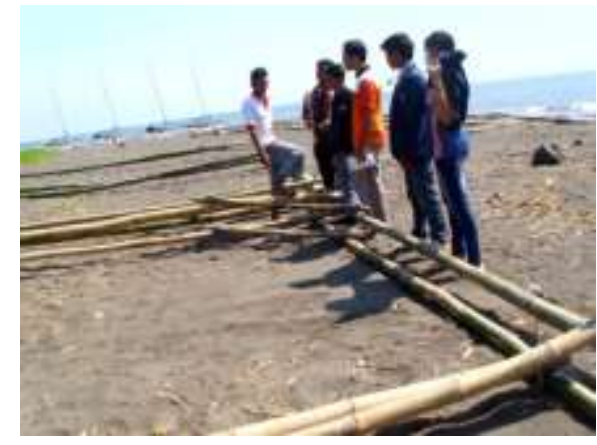

Gambar 5. Ancak Tempat Tanam Rumput Laut 


\section{INTEGRITAS : Jurnal Pengabdian}

Vol 2, No 2, Desember 2018

ISSN 2580-7978 (Cetak) ISSN 2615-0794 (Online)

Penanaman bersama dilaksanakan pada tanggal 11 Juni 2014. Hasil produksi rumput laut tersebut nantinya tidak dijual melainkan dijadikan bibit untuk dikembangkan dan dibagikan keanggota kelompok lainnya sebagai salah satu solusi mengatasi kekurangan permodalan utamanya penyediaan bibit dalam mengembangkan usahatani rumput laut.

\section{f.Pengklasifikasian dan pemberian nama ilmiah untuk ditempatkan di wisata.}

Di lokasi wisata pantai Patek terdapat jenis - jenis tanaman tahunan atau kayu-kayuan, tanaman tersebut memiliki beberapa fungsi antara lain sebagai penahan erosi air laut, pelindung, bahkan beberapa pohon yang ada mempunyai nilai ekonomis yang cukup tinggi seperti kayu mimbo dan gamelina. Proses pembuatan tanggal 1 Juni 2014 dan di pasang pada tanggal 20 Juli 2014 pada saat bulan puasa dengan harapan pada liburan hari Raya Idul fitri puncakpuncaknya pengunjung pantai Patek .Nama - nama ilmiah yang dipasang di pohon-pohon dapat memunculnya rasa ketertarikan masyarakat terutama anakanak sekolah untuk membaca dan pada akhirnya menjadi tau nama latin dari pohon-pohon tersebut seperti misal nama latin dari mangga Mangifera indica ,secara tidak langsung masyarakat ikut serta dalam mendukung program agrowisata Kabupaten Situbondo dan program edutourism dapat tercapai.

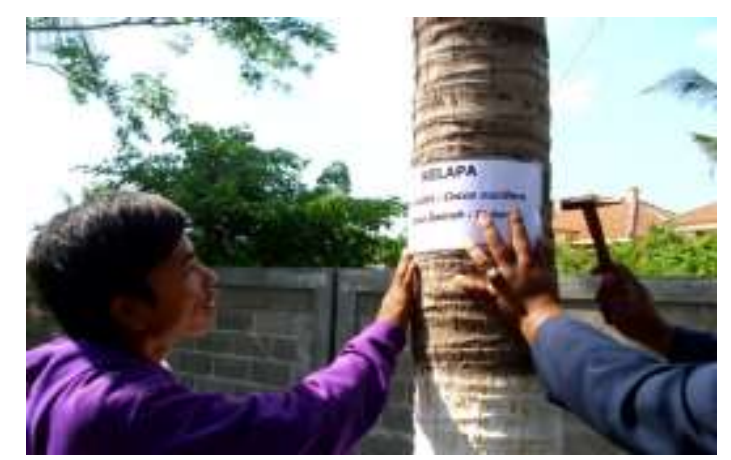

Gambar 6. Pemasangan Label Ilmiah di Pohon Sekitar Tempat Wisata 


\section{INTEGRITAS : Jurnal Pengabdian}

Vol 2, No 2, Desember 2018

ISSN 2580-7978 (Cetak) ISSN 2615-0794 (Online)

\section{g.Potensi sector Perikanan}

Salah satu potensi yang dimiliki desa Gelung adalah sektor perikanan, dimana sebagian besar penduduk desa Gelung bermata pencahariaan sebagai nelayan, hasil tangkapan mereka umumnya di jual pada tengkulak yang datang ke desa Gelung, namun bila hasil tangkapan berlebih atau tidak laku dijual biasanya nelayan menjual ikannya dalam bentuk ikan kering yaitu dengan cara di jemur terlebih dahulu ini akan menolong mereka dari kerugian.

Program Kluster Sains dan Teknologi-Pengelolaan Lingkungan dan Tata Kelola.

\section{a. Program short course, pelatihan computer dan pengenalan wawasan IT}

Satu hal yang juga menjadi kendala yaitu rendahnya masyarakat di bidang teknologi informasi utamanya komputer kondisi ini terlihat dari sarana prasarana yang di miliki kantor desa masih belum menggunakan komputer dalam pelayanan publik . Program bisa dijadikan solusi dalam mengatasi persoalan tersebut diatas dan ini tidak dijadwal secara khusus namun dilakukan di sela-sela kegiatan lain seperti pada pada saat jam-jam istirahat kerja perangkat desa juga diajari, pertemuan-pertemuan PKK, pada saat ada arisan atau saat mereka kumpulkumpul duduk bersama keluarga. Sasaran program ini adalah pemuda yang ada di Desa Gelung dengan harapan terdapat peningkatan ketrampilan masyarakat di bidang IT, mengingat informasi teknologi saat ini sudah tidak bisa dihindari lagi.

\section{b.Pengecatan Tembok Pagar Balai Desa}

Salah satu program KKN PPM adalah pengecatan tembok pagar balai desa yang dilaksanakan setiap hari sabtu pada saat kantor desa libur sehingga tidak mengganggu aktifitas kegiatan pelayanan oleh peserta KKN PPM secara bersamasama. Pengecatan dilakukan dalam rangka pemeliharaan sehingga kantor terlihat lebih bersih rapi dan indah. 


\section{INTEGRITAS : Jurnal Pengabdian}

Vol 2, No 2, Desember 2018

ISSN 2580-7978 (Cetak) ISSN 2615-0794 (Online)

\section{c.Pembuatan dan Pemasangan Denah Desa}

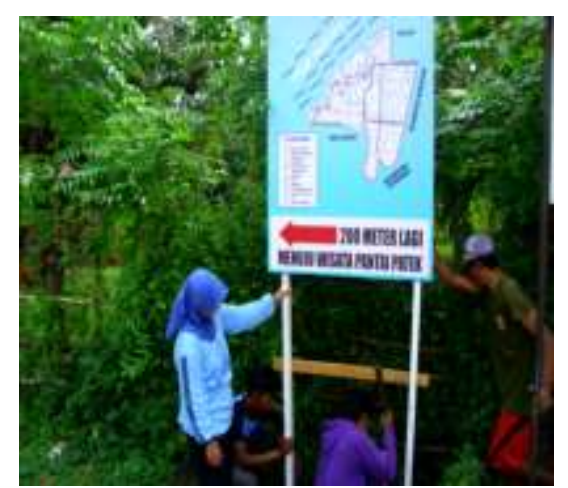

Gambar 7. Pemasangan Denah Desa

Dalam rangka meningkatkan informasi dan untuk memudahkan masyarakat atau wisatawan yang datang ke pantai Patek adanya denah desa sangat membantu dan mempermudah menuju akses ke tempat wisata. Pemasangan dilakukan pada tanggal 19 Juli 2014 adanya denah desa di sambut baik oleh warga terbukti ketika pemasangan denah warga antusias membantu mendirikan denah tersebut.

\section{d.Letterisasi}

Kondisi tulisan nama kantor desa sebelumnya banyak yang sudah rusak dan tulisannya hilang, program letterisasi bertujuan untuk perbaikan tulisan nama Kantor Desa Gelung yang lebih baik dan indah.Pemesanan letterisasi pada tanggal 14 Juni 2014 dan pemasangan dilakukan pada tanggal 13 Juli 2014 oleh peserta KKN PPM.

\section{e.Pengembangan Hard Skill}

Di era tansformasi teknologi informasi dan komunikasi, masyarakat diajari internet pada tanggal 26-27 Juni 2014 agar tidak buta internet dan dapat membuka akses informasi apapun di internet sehingga pengetahuan masyarakat di bidang IT meningkat hal ini sangat positif mengingat Desa Gelung memiliki banyak potensi karena bisa di jadikan ajang promosi. Dan dengan telah dibuatnya web maka masyarakat dapat mengakses info apapun tentang Gelung dengan segala potensi yang ada di web tersebut. 


\section{INTEGRITAS : Jurnal Pengabdian}

Vol 2, No 2, Desember 2018

ISSN 2580-7978 (Cetak) ISSN 2615-0794 (Online)

\section{Kegiatan lainnya}

Peserta KKN PPM selain melaksanakan kegiatan utama, penunjang, dan saintek juga melaksanakan kegiatan lainnya seperti posyandu, pengajian, lombalomba, membantu administrasi desa, promo produk unggulan Desa Gelung, keaksaraan fungsional, persami, dan pramuka.

\section{a. Posyandu}

Membantu kegiatan posyandu pada tanggal 2 Mei 2014 dan tanggal 2 Juni 2014, yakni penimbangan balita dan memberikan PMT program makan tambahan ,vaksinasi balita.

\section{b.Pengajian}

Mahasiswa menghadiri kegiatan pengajian Isro' mi'roj pada tanggal 27 Mei 2014, siraman rohani yang diperoleh pada saat mengikuti pengajian sangat besar manfaatnya bagi peserta KKN PPM sebagai penyejuk jiwa.

\section{c.lomba-Lomba}

Lomba-lomba diadakan dalam rangka memperingati hari Kebangkitan Nasional dan pelaksanaan pada tanggal 29 Mei 2014. Macam-macam lomba antara lain tarik tambang dan lomba balap karung, memukul kantong air dengan mata tertutup,tujuan kegiatan ini semata-mata untuk keakraban antara mahasiswa dengan masyarakat setempat.

\section{d.Admisistrasi Desa}

Selain kegiatan tersebut diatas mahasiswa membantu perangkat desa dalam kegiatan administrasi lebih-lebih menjelang pilihan presiden 9 Juli 2014 ,banyak persiapan yang dilakukannya seperti flouchart rekapitulasi data perolehan suara,dan lain-lain

\section{e.Promo Produk Unggulan}

Mahasiswa mempromosikan produk unggulan Desa Gelung seperti rengginang dan kerupuk ikan pada pengunjung pantai Patek.Kegiatan dilakukan pada hari minggu tanggal 25 Mei 2014.Para pengunjung yang sedang dudukduduk bersantai di tepi pantai ditawari oleh peserta KKN PPM rengginang dan 


\section{INTEGRITAS : Jurnal Pengabdian}

Vol 2, No 2, Desember 2018

ISSN 2580-7978 (Cetak) ISSN 2615-0794 (Online)

kerupuk ikan dan yang berminat langsung membelinya karena harga yang relative murah atau terjangkau kedua produk tersebut laku terjual bahkan ada yang membelinya lebih dari 3 bungkus.

\section{f.Persami}

Mahasiswa bekerjasama dengan SDN I Gelung mengadakan Perkemahan Sabtu - Minggu yang dilaksanakan pada tanggal 10-11 Mei 2014 dan diikuti oleh siswa - siswi kelas V dan VI. Tujuan dari Persami mengajari siswa-siswi belajar kerjasama dalam kelompok, mengekpresikan bakat seni yang bisa ditampilkan pada acara tersebut.

\section{g.Pramuka}

Kegiatan ini dilaksanakan 2 kali yakni pada tanggal 16 Mei 2014 dan 30 Mei 2014,Tujuannya membekali siswa-siswi dengan sikap mandiri, kebersamaan, baris berbaris serta kedisiplinan agar kelak siswa-siswi dewasa memiliki pribadi yang kuat dan tangguh.

\section{h.Keaksaraan Fungsional.}

Dalam rangka mencerdaskan bangsa dan membantu program pemerintah memberantas buta aksara untuk melek huruf dan melek angka, mahasiswa mengajak masyarakat yang masih belum bisa membaca dan menulis untuk diajari. kegiatan ini dilaksanakan sebanyak 4 kali pertemuan selama bulan Mei dan Juni 2014.Hambatan kegiatan ini ialah waktu pelaksanaan yang terbatas sehingga peserta keaksaraan fungsional belum benar-benar bisa baca dan nulis.

\section{KESIMPULAN}

Program KKN PPM di Desa Gelung Kecamatan Panarukan Kabupaten Situbondo telah dilaksanakan selama 3 bulan dan berjalan lancar serta semua progam dilaksanakan dengan baik walaupun kedepan sangat diperlukan adanya program lanjutan seperti pedampingan atau bentuk kegiatan pelatihan, penyuluhan, pemeliharaan, dalam rangka peningkatan produksi dan kualitas produk serta kualitas layanan, catatan usaha pada tingkat UMKM sehingga dihasilkan manajemen pengelolaan usaha yang baik dan demi sustainability 


\section{INTEGRITAS : Jurnal Pengabdian}

Vol 2, No 2, Desember 2018

ISSN 2580-7978 (Cetak) ISSN 2615-0794 (Online)

program pengabdian bagi masyarakat Desa Gelung .

Agar kiranya program ini bisa dilanjut dengan menggunakan skim-skim yang lain sepeti IbM yang kami usulkan ke DIKTI dengan judul "Mengajari membuat catatan usaha pada petani rumput laut dan UMKM di Desa Gelung Kecamatan Panarukan Kabupaten Situbondo, dengan harapan diterima dan bisa didanai oleh DP2M pada tahun berikutnya.

\section{REFERENSI}

Anonim.2012. Pengelolaan Rumput Laut http://algacorp.blogspot.com/p/pengelolaanrumput-laut.html, diakses tanggal 05 Mei 2014

.2013. Buku Panduan KKN PPM Unveritas Abdurachman Saleh Situbondo

Devi D.2013. cara pengolahan rumput laut yang benar.

http://carapengolahan.blogspot.com/, diakses tanggal 05 Mei 2014

Kurniawan.Iwan.2012.HukumKepariwisataan. satyagazzy.files.wordpress.com/2012/01/ Dikases tanggal 17 Juli 2014

Purnama,Adi."Diversifikasi Pangan Untuk Mengatasi Krisis Pangan Di Indonesia". Bogor Agricultural University - http://www.ipb.ac.id., diakses tanggal 17 juli 2014

Setiawan,budi.2012.”Optimalisasi Diversifikasi Pangan Guna Mewujudkan Ketahanan Pangan Yang Berkelanjutan”.Majalah Tannas Edisi 94-2012. http://www.lemhannas.go.id/portal/, diakses tanggal 17 Juni 2014

Surakusuma.wahyu.Ekowisata. http://file.upi.edu/Direktori/, diakses tanggal 10 Mei 2014 